\title{
TESES
}

\section{De vocação para profissão: organização sindical docente e identidade social do professor}

Erlando da Silva Rêses

Curso: Doutorado em Sociologia

Data da defesa: 2 de junho de 2008

Orientador: Prof. Dr. Sadi Dal Rosso

\section{Resumo}

O sindicalismo operário surge no século XIX e se desenvolve com grandes mobilizações sociais durante as primeiras décadas do século XX, no Rio de Janeiro. Registra-se, nesse período, a existência de greves que envolveram diversas categorias profissionais. E o setor educacional, como se encontrava? As condições da escola pública eram precárias, o analfabetismo, alarmante e a profissão de professor, desvalorizada, devido à existência de poucas escolas oficiais. O estímulo ao ingresso no Ensino Superior pelas camadas mais abastadas da sociedade, à época, motivava a proliferação do ensino particular. Diante de tais fatos, o estudo averiguou se a formação da organização sindical docente da Educação Básica no Rio de Janeiro foi tardia, comparativamente à estruturação das organizações sindicais operárias, tarefa que exige reconstruir a origem do sindicalismo docente e as condições de sua emergência.

Para a consecução do objetivo da análise da formação tardia ou não do sindicalismo docente, realizou-se pesquisa documental 
e levantamento de dados primários e secundários. Fizeram-se entrevistas em profundidade com 18 sujeitos com vinculação direta ou indireta ao sindicalismo docente da Educação Fundamental no Rio de Janeiro, dirigentes sindicais, ex-dirigentes e professores com atuação tanto no Sindicato dos Professores do Município do Rio de Janeiro e Região (Sinpro-Rio), quanto no Sindicato Estadual dos Profissionais da Educação do Rio de Janeiro (Sepe/ $\mathrm{RJ}$ ). Desenvolveu-se um repertório teórico-empírico que abrangeu discussão sobre a identidade social do professor, a proletarização do trabalho docente e trabalho por vocação, o panorama histórico e sociológico do sindicalismo operário brasileiro, o percurso do associativismo e da formação da perspectiva sindical no Brasil, a tessitura social, política, econômica e educacional do Rio de Janeiro nos últimos momentos do período monárquico até as primeiras décadas do período republicano. A discussão sobre a identidade social do professor serviu para embasar a posição dessa categoria quanto à classificação como "trabalhador". Porém, o que se verificou foi a existência de ambigüidades. A tese da proletarização dos professores ganhou força, na atualidade, com a intensificação do trabalho docente e o alargamento da condição de assalariado.

$\mathrm{Na}$ análise dos dados das entrevistas, utilizou-se o programa Alceste e a abordagem tridimensional do sociólogo francês Doise, que apresenta três fases ou hipóteses de análise: existência de um campo comum nos discursos dos sujeitos, diferenças individuais ou grupais e ancoragem dessas diferenças. No campo comum, os sujeitos revelaram a imprescindibilidade do sindicato para o reconhecimento e a valorização da categoria. Já nas diferenças grupais, averiguou-se que o grupo de professores com história de filiação ao sindicalismo docente do ensino público destacou que a identidade social do professor passa pela classificação da categoria como classe trabalhadora e apresentou um sindicalismo mais ativo e mobilizador. Para esse grupo, o trabalho por vocação contribuiu significativamente para a demora na organização sindical da categoria. 
O grupo de professores com história de filiação ao sindicalismo docente do ensino privado apresentou uma visão mais imobilista da categoria, destacando aspectos da sua própria história de militância, em que prevaleceu o personalismo e o centralismo de decisões. A ancoragem vinculou-se com a história de formação do dirigente sindical, da sua percepção sobre sindicalismo e educação e de sua vinculação ao tipo de sindicato, se atrelado à estrutura sindical oficial ou não. Os resultados da pesquisa apontaram para a existência de multifatores impeditivos para a organização sindical dos professores da rede pública no Rio de Janeiro: ambigüidade da identidade social da profissão de professor; baixa densidade de professores; elitismo dos professores na Primeira República; enquadramento sindical e ausência de sindicalismo autônomo; concepção de vocação, missão ou dom para o exercício do magistério; desorganização estrutural do ensino público e sua desvalorização pelo Estado, limitação legal do Estado para a organização sindical no serviço público.

Percebeu-se uma similitude no percurso da organização sindical entre o Rio de Janeiro e Portugal. Nas duas localidades, o mutualismo favoreceu a formação da forma-sindicato entre os docentes, com a diferença de que, em Portugal, ela se inicia na segunda metade do século XIX e, no Rio de Janeiro, no começo do século XX. No Rio de Janeiro, a primeira organização sindical docente surge em 1931, com os professores do Ensino Secundário da rede privada. Já em Portugal, ela aparece em 1911, com o Sindicato dos Professores Primários do ensino oficial no Porto. Em ambos os locais, o movimento sindical docente ganha amplitude após os anos 1970.

Palavras-chave: sindicalismo; sindicalismo docente; trabalho docente; identidade social; identidade profissional. 